ZOOLOGIA 28 (6): 819-830, December, 2011

doi: $10.1590 /$ S1984-46702011000600016

\title{
Taxonomic review of Metaxia (Gastropoda: Triphoridae) from Brazil, with description of a new species
}

\author{
Maurício Romulo Fernandes \& Alexandre Dias Pimenta
}

Departamento de Invertebrados, Museu Nacional, Universidade Federal do Rio de Janeiro. Quinta da Boa Vista, São Cristóvão, 29040-040 Rio de Janeiro, RJ, Brazil. E-mail: mauriciofernandes14@hotmail.com; adpimenta@yahoo.com.br

\begin{abstract}
The taxonomy of the species of Metaxia Monterosato, 1884 from Brazil is revised. Previously to this study, only Metaxia excelsa Faber \& Moolenbeek, 1991 was known to occur in this country, under its older name Metaxia exilis (C.B. Adams, 1850). The review of a large amount of shells in malacological collections in Brazil revealed the occurrence of three known additional species: Metaxia taeniolata (Dall, 1889); Metaxia rugulosa (C.B. Adams, 1850); Metaxia prompta Rolán \& Fernández-Garcés, 2008, all previously reported from the southeast coast of the USA and/or the Caribbean region. Metaxia gongyloskymnus sp. nov., diagnosed by the globose protoconch with continuous axial ribs and microscopic spiral sculpture, is restricted to localities off the Southeastern Brazilian coast.
\end{abstract}

KEY WORDS. Marine mollusks; Metaxiinae; Mollusca; Triphoroidea; West Atlantic.

Triphoridae is a large group of marine microgastropods that includes both sinistral (left-coiled) and dextral (rightcoiled) species. The morphology of the protoconch is crucial to the proper classification of the species in the family (WeLLS 1998). The dextral species are all included in Metaxiinae, that is characterized by the presence of crisp, zigzag spiral cords on the first embryonic whorls and subsequent whorls axially ribbed (Marshall 1977) and includes the 28 described species of Metaxia Monterosato, 1884 (Appeltans et al. 2011), which are distributed worldwide in tropical and temperate seas (MARSHALL 1983).

The taxonomic knowledge on species of Metaxia in the western Atlantic was expanded considerably by several recent contributions, especially from the Caribbean region (ROLÁn \& Fernández-Garcés 1992, 2007, 2008, Rolán \& Redfern 1996). A total of eleven species are presently known from the western Atlantic (Rosenberg 2009, Faber 2010). There are two cases of amphi-Atlantic species (Fernandes \& Rolán 1994), although BOUCHET (1985) considered the occurrence of Metaxia abrupta (Watson, 1880) in the western Atlantic to be doubtful. Most of these eleven species are restricted to the northwestern Atlantic (Caribbean and the south-southeast coast of the USA). The only species recorded from the southwestern Atlantic is Metaxia excelsa Faber \& Moolenbeek, 1991, which was recorded from Pará to Rio de Janeiro states, under its older name Metaxia exilis (C.B. Adams, 1850) (e.g., LeAl 1991, Rios 1994, 2009).

Examination of Brazilian malacological collections, as well as the study of material from recent expeditions off the southeast Brazilian coast, revealed several lots that were determined as M. exilis, but actually containing five different species of this genus.

\section{MATERIAL AND METHODS}

The taxonomic identifications were based on conchological comparisons with original descriptions and illustrations. Each species was illustrated using scanning electron microscope (SEM) images. In the lists of material examined, the number of shells in each lot is indicated before the abbreviation "sh". The abbreviation " $\mathrm{m}$ " refers to the depth (in meters) of the collecting locality.

The terminology used for shell descriptions and the procedure of whorls count was based on LeAL (1991).

The following malacological collections provided material for this revision: Instituto de Biologia/UFRJ, Rio de Janeiro (IBUFRJ); Museu Nacional, UFRJ, Rio de Janeiro (MNRJ); Muséum national d'Histoire naturelle, Paris (MNHN); Museu Oceanográfico do Rio Grande, Rio Grande (MORG); Museu de Zoologia, USP, São Paulo (MZUSP); Universidade do Estado do Rio de Janeiro, Rio de Janeiro (UERJ).

Other abbreviations used through the text include: (AG) supply boat N/RB Astro Garoupa; (AMASSEDS) A Multidisciplinary Amazon Shelf Sedimentary Study, Research Vessel 'Columbus Iseling' leg.; (Eq. RAP Ilha Grande) team of the Rapid Acessment Protocol at Baía da Ilha Grande, Rio de Janeiro; (FLMNH) Florida Museum of Natural History, Gainesville, Florida; (HAB) Projeto Habitats: "Heterogeneidade Ambiental da Bacia de Campos" (Habitats Project: Campos Basin Environmental Heterogeneity), carried out by CENPES/PETROBRAS, Research Vessel Miss Emma McCall leg.; (MCZ) Museum of Comparative Zoology, Cambridge; (MD 55) Oceanographic cruise Marion Dufresne, southeast Brazil, 1987, Research Ves- 
sel Marion Dufresne leg.; (REVIZEE) "Programa de Avaliação do Potencial Sustentável de Recursos Vivos da Zona Econômica Exclusiva" (Program of Evaluation of the Sustainable Potential of Living Resources in the Economic Exclusive Zone), score Central, from Salvador $\left(13^{\circ} \mathrm{S}\right)$ to São Tomé Cape $\left(22^{\circ} 30^{\prime} \mathrm{S}\right)$, carried out by Ministério do Meio Ambiente, Brazilian Government (REVIZEE C1, Oceanographic Ship Antares leg.; REVIZEE C2, C5, C6, supply boat N/RB Astro Garoupa leg.); (USNM) National Museum of Natural History, Washington D.C.

\section{TAXONOMY}

\section{Metaxia Monterosato, 1884}

Type species: according to Bouchet (1985): Cerithium rugulosum Sowerby, 1855 (non C.B. Adams, 1850) (= Cer. metaxae Delle Chiaje, 1828?), subsequent designation by Cossmann (1906). Europe.

Diagnosis. Based on Marshall $(1977,1983)$ and Wilson (1993): dextral coiling shell; protoconch with lecitotrophic or planctotrophic development, with two to five whorls, first whorl with fine zigzag spiral threads, the others with spiral lines and fine axial riblets; teleoconch with convex whorls sculptured with four to five spiral cords per whorl crossed by strong axial lines resulting in nodular intersections; anterior canal as a simple and large notch; periostracum axially lamellar; rhinioglossate radula with formula $8-9+1+1+1+9-8$.

\section{Metaxia excelsa Faber \& Moolenbeek, 1991}

\section{Figs 1-6}

Cerithium exile C.B. Adams, 1850 (non Eichholtz, 1829): 120; Clench \& Turner (1950: 279, pl. 38, fig. 8).

Cerithiopsis exilis: Rios (1970: 44; 1975: 48, pl. 13, fig. 175; 1985 : 50, pl. 19, fig. 223).

Metaxia exilis: Jong \& Coomans (1988: 51); Leal (1991: 124, pl. 17, figs E-F); Rios (1994: 95, pl. 31, fig. 381; 2009: 175, fig. 420); Absalão et al. (2006: 238, in part); Gomes et al. (2006: 187).

Metaxia excelsa Faber \& Moolenbeek, 1991: 83: Rolán \& Fernández-Garcés (1992: 172, figs 1, 7; 2007: pl. IV, figs 68); Redfern (2001: 69, pl. 34, fig. 291); Lee (2009: 90).

Type material: Holotype MCZ 177150 (examined). Type locality: Jamaica.

Characterization. Shell elongated, slender and conical, reaching $4.4 \mathrm{~mm}$ in length, $1.1 \mathrm{~mm}$ in width. Protoconch narrow, elongated and subcylindrical, with around 4.5 whorls; first whorl dome shaped with fine and numerous zigzag spiral lines, closely spaced; remaining whorls with keeled outline, with predominant axial riblets somewhat discontinuous at middle of whorl and irregular, tiny, somewhat spiral growth lines. Teleoconch with up to nine convex whorls; sculpture by 13 equally strong axial ribs on eighth whorl crossed by four spiral cords per whorl, the first, adapical one located just below suture is very thin on initial whorls, becoming stronger towards last whorls; prominent nodules formed at the crossing of axial ribs and the three abapical spiral cords, slightly larger on the median one; one or two additional very thin cordlets at suture; last whorl with strong, smooth, slightly wavy subperipheral cord; base short and concave; aperture almost round, with short siphonal notch; outer lip thin; columellar lip sinusoidal. Color light brown to somewhat dark brown, nodules usually whitish. Material examined. Brazil, Amapá: (AMASSEDS sta 4134, $02^{\circ} 21^{\prime} 00^{\prime \prime} \mathrm{N}, 48^{\circ} 29^{\prime} 00^{\prime \prime} \mathrm{W}, 72 \mathrm{~m}$ ), 3 sh, iii/1997, MORG 43262. Maranhão: (Santana Island, 38 m), 1 sh, 28/xi/1967, MORG 18254. Pernambuco: Fernando de Noronha Archipelago, 1 sh, Eq. MORG leg., MORG 20615; Fernando de Noronha Archipelago (40 m), 7 sh, 05/xii/1985, M. Cabeda leg., MORG 24599. Alagoas: Maceió (Jaraguá), 3 sh, vii/1967, MORG 18260. Bahia: Salvador, 1 sh, xi/1991, G. Oliveira leg., MORG 41455; Baía de Camamú, 2 sh, xii/2001, V. Abud \& M. Ximenez leg., MNRJ 15325; (REVIZEE sta C5-4R, $14.808^{\circ} \mathrm{S}, 38.917^{\circ} \mathrm{W}, 20 \mathrm{~m}$ ), 01/vii/ 2001, 1 sh, IBUFRJ 14534; (REVIZEE sta C1-C76, 1553'49"S, $38^{\circ} 31^{\prime} 05^{\prime \prime} \mathrm{W}, 66 \mathrm{~m}$ ), 30/iv/1996, 2 sh, MNRJ 15813; (REVIZEE sta C5-13R, $\left.16^{\circ} 47^{\prime} 08^{\prime \prime} \mathrm{S}, 38^{\circ} 41^{\prime} 08^{\prime \prime} \mathrm{W}, 50 \mathrm{~m}\right), 1 \mathrm{sh}, 30 / \mathrm{vi} / 2001$,

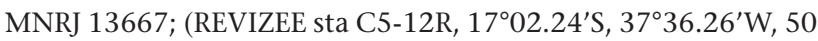
m), 1 sh, 30/vi/2001, IBUFRJ 13424. Espírito Santo: off Aracruz, 1 sh, 14/vi/1991, Eq. Zoo leg., IBUFRJ 5952; off Aracruz, 7 sh, 01/viii/1988, V. Abud leg., MORG 29054; off Tubarão, 1 sh, iii/ 1993, V. Abbud leg., MORG 39973; off Piúma, 13 sh, 1993, F. Pitombo leg., IBUFRJ 8520; (REVIZEE sta C5-25R, 19³1'06"S, $38^{\circ} 46^{\prime} 03^{\prime \prime} \mathrm{W}, 65 \mathrm{~m}$ ), 1 sh, 28/vi/2001, IBUFRJ 14631; (REVIZEE sta C5-25R, 19³1'06"S, 38 $\left.46^{\prime} 03^{\prime \prime} \mathrm{W}, 65 \mathrm{~m}\right), 1 \mathrm{sh}, 28 / \mathrm{vi} / 2001$, MNRJ 12772; (REVIZEE sta C1-C63, 1940'42"S, 3808'15”W, $61 \mathrm{~m}$ ), 1 sh, 25/iv/1996, IBUFRJ 9277; (REVIZEE sta C1-VV38, $\left.19^{\circ} 44^{\prime} \mathrm{S}, 38^{\circ} 22^{\prime} \mathrm{W}, 71.4 \mathrm{~m}\right), 14 \mathrm{sh}, 29 / \mathrm{ii} / 1996$, IBUFRJ 13129; (REVIZEE sta C1-VV38, $19^{\circ} 44^{\prime} \mathrm{S}, 38^{\circ} 22^{\prime} \mathrm{W}, 71.4 \mathrm{~m}$ ), 6 sh, 29/ii/ 1996, MNRJ 15809; (REVIZEE C1-VV38, 19²4's, 38²2'W, 71.4 m), 2 sh, 29/ii/1996, UERJ 3097; (REVIZEE sta C1-VV24, 2000'S, $39^{\circ} 54^{\prime} \mathrm{W}, 45 \mathrm{~m}$ ), $3 \mathrm{sh}, 27 / \mathrm{ii} / 1996$, MNRJ 15815; (REVIZEE sta C5-20R, 20.19 $\left.27^{\prime} \mathrm{S}, 38^{\circ} 01^{\prime} \mathrm{W}, 67 \mathrm{~m}\right), 1$ sh, 28/vi/2001, MNRJ 12765; (REVIZEE sta C1-C62, 20³0'01"S, 37²8'30"W, $96 \mathrm{~m}$ ), 6 sh, 25/iv/1996, MNRJ 15814; (REVIZEE sta C1-C62, $20^{\circ} 30^{\prime} 01^{\prime \prime}$ S, 37²8'30”W, 96 m), 7 sh, 25/iv/1996, MORG 41102;

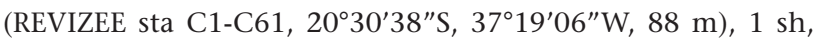
24/iv/1996, IBUFRJ 9307; (REVIZEE sta C1-C61, 20³0'38"S, $37^{\circ} 19^{\prime} 06^{\prime \prime} \mathrm{W}, 88 \mathrm{~m}$ ), 4 sh, 24/iv/1996, MNRJ 15816; (REVIZEE sta C1-C61, 20³0'38"S, 37¹9'06"W, 88 m), 16 sh, 24/iv/1996, MORG 40562; (REVIZEE sta C2-22R, 20³0'38"S, 3550'16"W, $59 \mathrm{~m}$ ), $1 \mathrm{sh}, 08 / \mathrm{xi} / 1997$, IBUFRJ 13145; (REVIZEE sta C1-VV21, $\left.20^{\circ} 38^{\prime} \mathrm{S}, 40^{\circ} 00^{\prime} \mathrm{W}, 56 \mathrm{~m}\right), 3 \mathrm{sh}, 27 / \mathrm{ii} / 1996$, MNRJ 15810; (REVIZEE sta C1-VV21, 20 $38^{\prime} \mathrm{S}, 40^{\circ} 00^{\prime} \mathrm{W}, 56 \mathrm{~m}$ ), 4 sh, 27/ii/

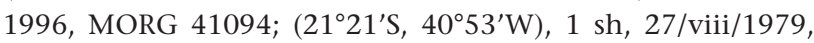
N.Oc. Almirante Câmara leg., IBUFRJ 6932; (HAB 17 sta I2, $\left.21^{\circ} 22^{\prime} 54.3^{\prime \prime} \mathrm{S}, 40^{\circ} 19^{\prime} 50.6^{\prime \prime} \mathrm{W}, 53 \mathrm{~m}\right), 2 \mathrm{sh}, 21 / \mathrm{vii} / 2009$, MNRJ

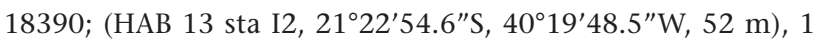
sh, 05/iii/2009, MNRJ 16241; (HAB 13 sta H5, 2142'33.1"S, 409'5.99”W, 147 m), 1 sh, 09/iii/2009, MNRJ 16242; (HAB 13 


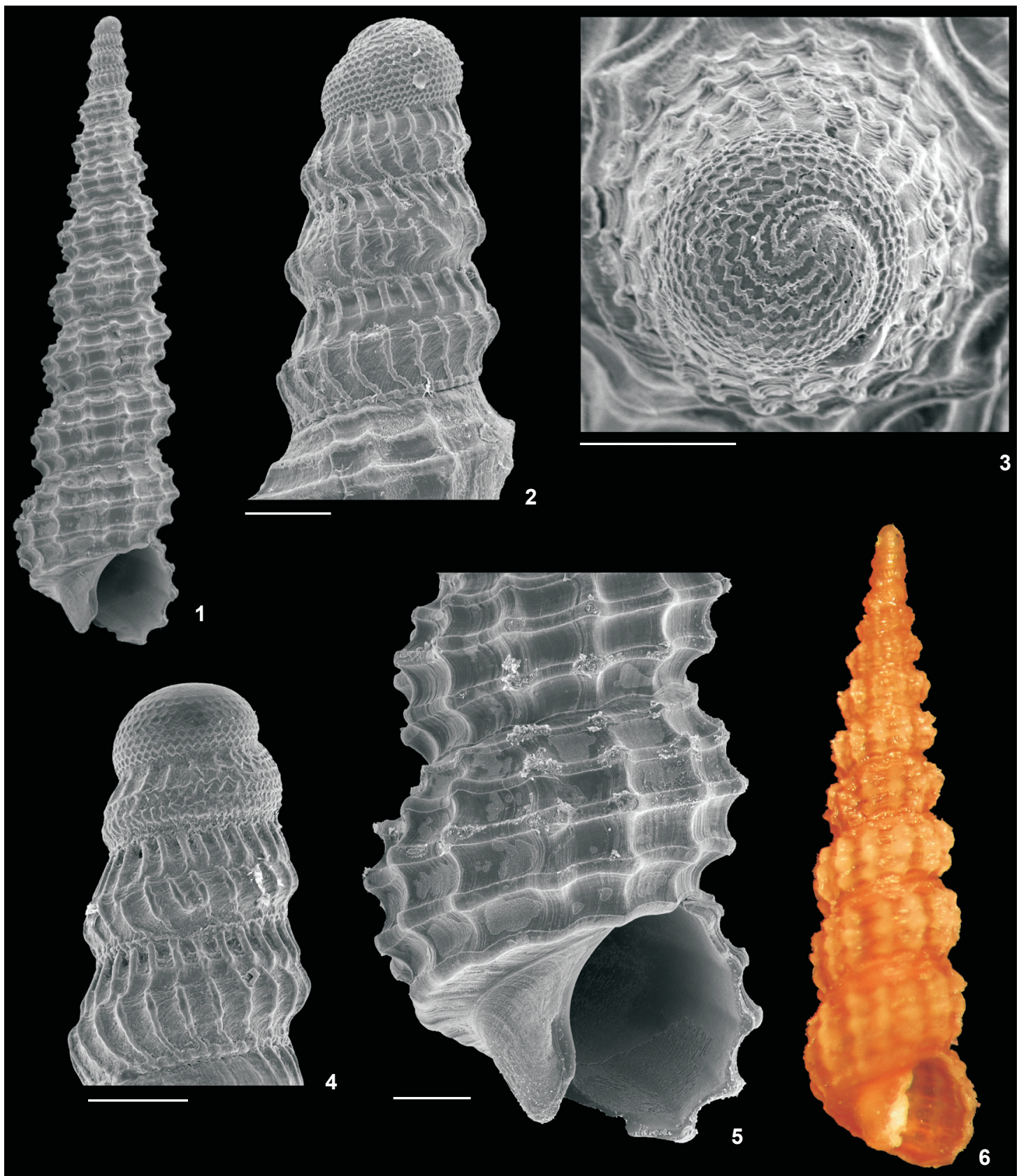

Figures 1-6. Metaxia excelsa: $(1,6)$ whole shell, respective lengths: $3.56,3.75 \mathrm{~mm}$; $(2-4)$ protoconch; (5) last whorl. (1-3, 5) MNRJ 18390; (4) MNRJ 15325; (6) MNRJ 25036. Scale bars: 2-4 = $100 \mu \mathrm{m}, 5=200 \mu \mathrm{m}$.

sta H4, 21 $\left.42^{\prime} 49.3^{\prime \prime} \mathrm{S}, 40^{\circ} 10^{\prime} 21.4^{\prime \prime} \mathrm{W}, 98 \mathrm{~m}\right), 1 \mathrm{sh}, 09 / \mathrm{iii} / 2009$, MNRJ 16243; Davis Seamount, Vitória-Trindade Chain (MD55 sta DC41, $\left.20^{\circ} 39^{\prime} \mathrm{S}, 34^{\circ} 43^{\prime} \mathrm{W}, 58-70 \mathrm{~m}\right), 1 \mathrm{sh}, 17 / \mathrm{v} / 1987$, MNRJ 25036. Rio de Janeiro: (MD55 sta DC15, $21^{\circ} 37^{\prime} \mathrm{S}, 40^{\circ} 18^{\prime} \mathrm{W}, 37$ $\mathrm{m}), 1 \mathrm{sh}, 11 / \mathrm{v} / 1987$, MNRJ 25035; (HAB 16 sta G3, 22³'41.0”S, $\left.40^{\circ} 10^{\prime} 5.38^{\prime \prime} \mathrm{W}, 75 \mathrm{~m}\right), 1$ sh, 06/vii/2009, MNRJ 18424; (HAB 11 sta C4, 22 $\left.51^{\prime} 57.5^{\prime \prime} \mathrm{S}, 40^{\circ} 57^{\prime} 35.1^{\prime \prime} \mathrm{W}, 92 \mathrm{~m}\right), 2 \mathrm{sh}, 22 / \mathrm{ii} / 2009$, MNRJ 16245; (REVIZEE sta C1-D3, 22 $\left.52^{\prime} \mathrm{S}, 4^{\circ} 09^{\prime} \mathrm{W}, 80 \mathrm{~m}\right), 1$ sh, 23/ii/1996, MORG 39710; (2304'14.3"S, 4059'30.7”W), 1

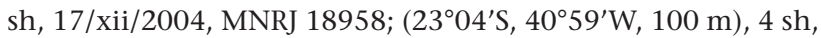
17/xii/2004, MORG 50153; Bacia de Campos, 2003, 1 sh, MORG 47483. 
Geographic distribution. USA: Florida (LeE 2009), Louisiana (Rosenberg 2009); Bahamas (Redfern 2001); Cuba (Rolán \& FernándeZ-GarCÉs 1992); Jamaica (type locality); Belize (Lee 2009); Costa Rica (Rosenberg 2009); Aruba, Bonaire and Curaçao (ABC Islands) (Jong \& CoOmans 1988); BraziL: Amapá (this study), Pará to Rio de Janeiro (Rios 1985), Fernando de Noronha and Abrolhos Archipelago (Rios 1985, LeAl 1991, Gomes et al. 2006), Vitória-Trindade Chain (Leal 1991).

Remarks. Although Faber \& Moolenbeek (1991) created the new name Metaxia excelsa for M. exilis (C.B. Adams, 1850) non Cerithium exile Eichholtz, 1829, all literature on Brazilian mollusks continued to use the older, preoccupied name, M. exilis (e.g., Rios 1994, 2009, AbsalÃo et al. 2006, Gomes et al. 2006, SANTos et al. 2007). This was the only species of Metaxia reported from Brazil, but previous records proved to be mixed with the other four taxa studied in this paper.

\section{Metaxia taeniolata (Dall, 1889)}

Figs 7-11

Cerithiopsis metaxae var. taeniolata Dall, 1889, 18: 256; Abbott (1974: 109).

Cerithiopsis rugulosum: Merlano \& Hegedus (1994: 146, pl. XLVI, fig. 512), non C.B. Adams, 1850.

Metaxia exilis: Absalão et al. (2006: 238, in part); Santos et al. (2007: 226, in part); non C.B. Adams, 1850.

Metaxia excelsa: Tunnell Jr et al. (2010: 205), non Faber \& Moolenbeek (1991).

Metaxia taeniolata: Rolán \& Fernández-Garcés (1992: 173-174, figs 3, 8; 2007: pl. IV, figs 13-14); Camp et al. (1998: 22).

Type material: Syntypes: USNM 92743, 92745, 92746 (not examined).

Type locality: off Carolina coast, USA.

Characterization. Shell elongated, slender and conical, reaching $5.0 \mathrm{~mm}$ in length, $1.1 \mathrm{~mm}$ in width. Protoconch narrow and elongated, with 3.5 to four whorls; first whorl dome shaped, with fine and numerous zigzag spiral cords, closely spaced; remainder whorls with convex, somewhat keeled outline, with predominant axial ribs and irregular, fine, somewhat spiral growth lines at the middle of the whorl. Teleoconch with up to eight convex whorls, and 13 strong axial ribs on seventh whorl, crossed by four spiral cords per whorl, the first, adapical one, located just below suture is very thin on initial whorls, becoming stronger towards last whorls; prominent nodules formed at the crossing of axial ribs and the three abapical spiral cords, slightly larger on the median one; an additional very thin cord just above suture; last whorl with smooth or slightly wavy subperipheral cord; base short and concave; aperture almost round; outer lip thin; columellar lip sinusoidal. Teleoconch white and even translucent in well preserved shells, with light brown spots at the inter-nodular spaces of second spiral cord around the fifth to the sixth whorl, becoming well sharp in the seventh whorl; light brown protoconch.
Material examined. BrazıL, Bahia: Salvador (Itapuã), 1 sh, ii/1990, P.M. Costa leg., MORG 27651; Salvador, 4 sh, xi/1991, G. Oliveira leg., MORG 51298. Espírito Santo: off Piúma, 4 sh, 1993, IBUFRJ 18947; (REVIZEE sta C1-C65, 1853'10"S, $\left.39^{\circ} 06^{\prime} 13^{\prime \prime} \mathrm{W}, 50 \mathrm{~m}\right), 1 \mathrm{sh}, 25 / \mathrm{iv} / 1996$, MNRJ 15808; (REVIZEE sta C1-C64, 19¹7'42"S, 38 42'02"W, 63 m), 1 sh, 25/iv/1996,

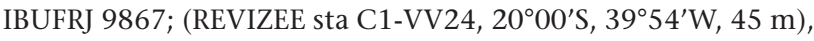
$1 \mathrm{sh}, 27 / \mathrm{ii} / 1996$, MNRJ 18746; (REVIZEE sta C1-VV22, $20^{\circ} 25^{\prime}$ 's, $40^{\circ} 05^{\prime} \mathrm{W}, 33 \mathrm{~m}$ ), 1 sh, 27/ii/1996, MNRJ 15811; (HAB 13 sta I2, $\left.21^{\circ} 22^{\prime} 54.6^{\prime \prime} \mathrm{S}, 40^{\circ} 19^{\prime} 48.5^{\prime \prime} \mathrm{W}, 52 \mathrm{~m}\right), 1 \mathrm{sh}, 05 / \mathrm{iii} / 2009$, MNRJ 18943; (HAB 13 sta H3, 214'ㄷ.94"S, 40¹1'36.9”'W, 73 m), 1 sh, 09/iii/2009, MNRJ 16244. Rio de Janeiro: (HAB 16 sta G3, $\left.22^{\circ} 3^{\prime} 41.0^{\prime \prime} \mathrm{S}, 40^{\circ} 10^{\prime} 5.38^{\prime \prime} \mathrm{W}, 75 \mathrm{~m}\right), 1 \mathrm{sh}, 06 / \mathrm{vii} / 2009$, MNRJ 18627; Baía da Ilha Grande (Ilha Comprida, $22^{\circ} 57.7^{\prime} \mathrm{S}, 44^{\circ} 22^{\prime} \mathrm{W}$, $6 \mathrm{~m}), 2$ sh, 29/x/2003, Eq. RAP Ilha Grande leg., UERJ 5762; Baía da Ilha Grande (Ilha da Gipóia, $23^{\circ} 1.9^{\prime} \mathrm{S}, 44^{\circ} 22.7^{\prime} \mathrm{W}, 6 \mathrm{~m}$ ), 2 sh, 28/x/2003, Eq. RAP Ilha Grande leg., UERJ 5803; Baía da Ilha Grande (Ilha dos Arrependidos, $23^{\circ} 2.6^{\prime} \mathrm{S}, 44^{\circ} 8.4^{\prime} \mathrm{W}, 16 \mathrm{~m}$ ), 1 sh, 02/xii/2003, Eq. RAP Ilha Grande leg., UERJ 5671; Baía da Ilha Grande (Enseada de Lopes Mendes, $23^{\circ} 10^{\prime} \mathrm{S}, 44^{\circ} 9^{\prime} \mathrm{W}, 15$ m), 1 sh, 04/xii/2003, Eq. RAP Ilha Grande leg., UERJ 5275; Baía da Ilha Grande (Ponta do Buraco, $23^{\circ} 14.2^{\prime} \mathrm{S}, 44^{\circ} 35.9^{\prime} \mathrm{W}$, $4.5 \mathrm{~m}), 1 \mathrm{sh}, 14 / \mathrm{xi} / 2003$, Eq. RAP Ilha Grande leg., UERJ 5880.

Geographic distribution. USA: Carolina coast (type locality), Florida (CAmp et al. 1998; Rosenberg 2009), Texas (Tunnell Jr et al. 2010); Cuba (Rolán \& Fernández-Garcés 1992), Colombia (Merlano \& Hegedus 1994); Brazil: Bahia to Rio de Janeiro (this study).

Remarks. Metaxia taeniolata (Figs 7-11) shares some similar characteristics with M. excelsa (Figs 1-6), including the narrow and elongated form of the protoconch (Figs 2, 4 and 8) and the presence of relatively large nodules on the teleoconch. However, the smaller number of whorls on the protoconch and, especially, the abrupt change in the coloration from the brown protoconch to the white teleoconch, clearly distinguish $M$. taeniolata (Fig. 11) from M. excelsa (Fig. 6).

\section{Metaxia rugulosa (C.B. Adams, 1850)} Figs $12-19$

Cerithium rugulosum C.B. Adams, 1850, 7: 121-122; Clench \& Turner (1950: 339, pl. 38, fig. 17).

Cerithiopsis bermudensis Verrill \& Bush, 1900: 536, pl. 65, fig. 20.

Cerithiopsis rugulosum: Abbott (1974: 109); Vokes \& Vokes (1983: 18, pl. 27, fig. 8).

Metaxia exilis: Absalão et al. (2006: 238, in part.), non C.B. Adams, 1850.

Metaxia rugulosa: Jong \& Coomans (1988: 51); Rolán \& FernándezGarcés (1992: 170, 172, figs 2, 9; 2007: pl. IV, figs 15-18); Camp et al. (1998: 22); Redfern (2001: 69-70, pl. 34, fig. 292, pl. 109, fig. 292); Lee (2009: 90); Tunnell Jr et al. (2010: 206).

Type material: Lectotype: MCZ 186153 (examined). Type locality: Jamaica. 


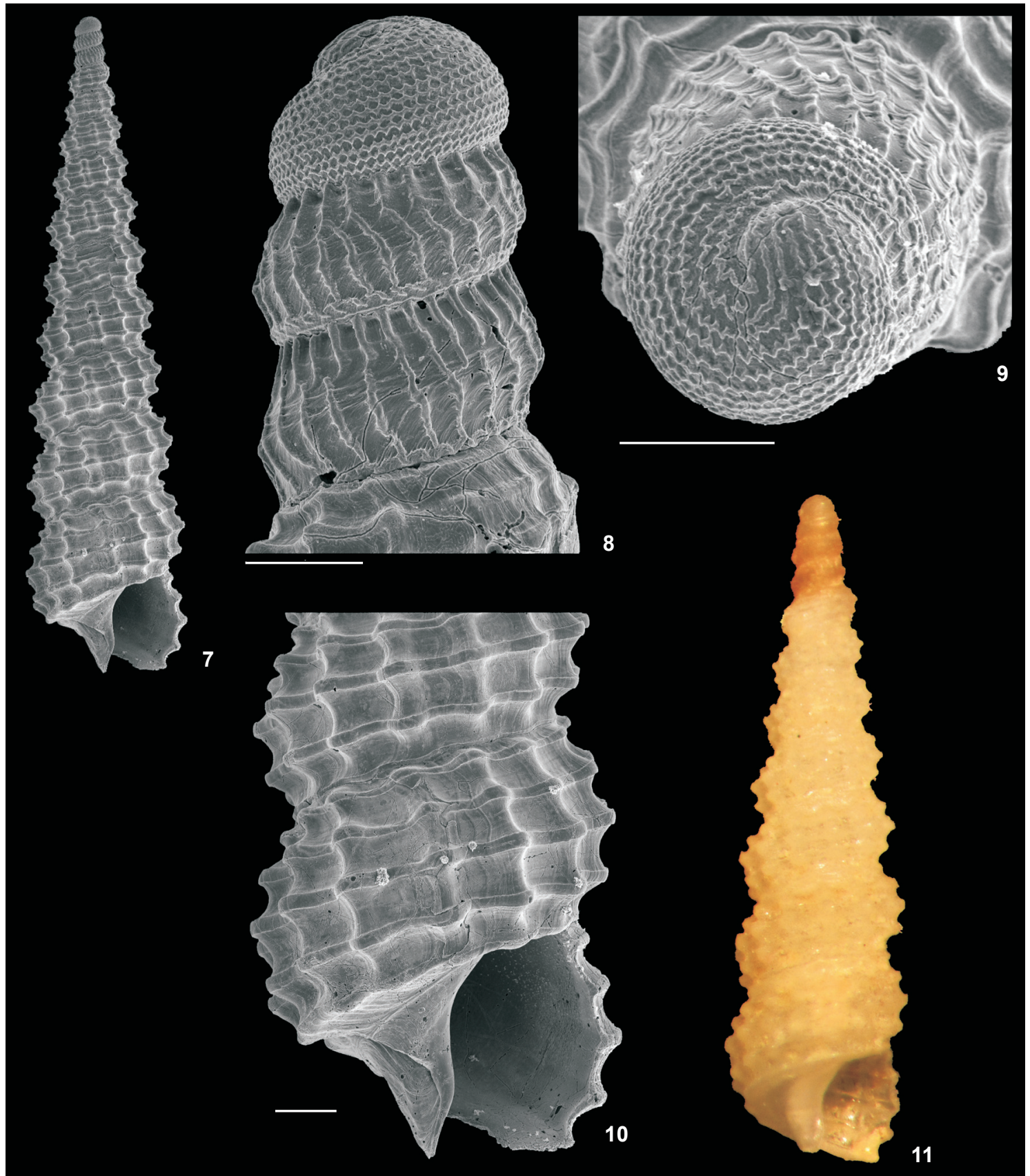

Figures 7-11. Metaxia taeniolata: $(7,11)$ whole shell, respective lengths: 4.51, $2.96 \mathrm{~mm}$; (8-9) protoconch; (10) last whorl. (7-10) MNRJ 15808; (11) MNRJ 18943. Scale bars: 8-9= $100 \mu \mathrm{m}, 10=200 \mu \mathrm{m}$.

Characterization. Shell elongated, slender and conical, reaching $6.0 \mathrm{~mm}$ in length, $1.1 \mathrm{~mm}$ in width. Protoconch wide, with 2.5 to three whorls, first whorl dome shaped or somewhat pointed; first whorl with zigzag spiral cords of varying expression, sometimes smooth or irregular, but threads always well spaced; second whorl with axial riblets varying in number and arrangement (curved or straight), and with one or two spirals cords. Teleoconch with up to 10 convex whorls; four spiral cords, with the adapical one being smaller and less nodulose; $\sim 13$ axial ribs on the eighth whorl, forming nodules of me- 
dium or even reduced size on intersections with the spiral cords; an additional small cord at suture; last whorl with strong and slightly irregular subperipheral cord; base short and concave; aperture almost round, with short siphonal notch; outer lip thin; columellar lip sinusoidal. Protoconch and teleoconch usually with equal tonalities of brown, light brown, beige and white.

Material examined. Brazil, Pará: 1 sh, 1970, MORG 15863. Bahia: (REVIZEE sta C1-C76, (1553'49"S, 38 31'05”W, 66 m), $1 \mathrm{sh}, 30 / \mathrm{iv} / 1996$, MNRJ 17898; (REVIZEE sta C5-13R, $\left(16^{\circ} 47^{\prime} 08^{\prime \prime} \mathrm{S}, 38^{\circ} 41^{\prime} 08^{\prime \prime} \mathrm{W}, 50 \mathrm{~m}\right), 1 \mathrm{sh}, 30 / \mathrm{vi} / 2001$, IBUFRJ 13425; Abrolhos Archipelago (Guarita Island, $5 \mathrm{~m}$ ), 2 sh, ii/ 1987, A. Silveira \& L. Laurino leg., MORG 26427. Espírito Santo: off Piúma, 2 sh, 1993, IBUFRJ 18946; (REVIZEE sta C1-VV33, $\left.18.888^{\circ} \mathrm{S}, 39.231^{\circ} \mathrm{W}, 37 \mathrm{~m}\right), 4 \mathrm{sh}, 28 / \mathrm{ii} / 1996$, MNRJ 17899 ;

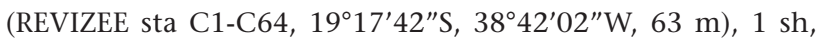
25/iv/1996, MNRJ 15812; (REVIZEE sta C1-VV38, 1944'S, $38^{\circ} 22^{\prime} \mathrm{W}, 71.4 \mathrm{~m}$ ), $11 \mathrm{sh}, 29 / \mathrm{ii} / 1996$, IBUFRJ 18949; (REVIZEE C1-VV38, $\left.19^{\circ} 44^{\prime} \mathrm{S}, 38^{\circ} 22^{\prime} \mathrm{W}, 71.4 \mathrm{~m}\right), 8$ sh, 29/ii/1996, UERJ 4202; (REVIZEE C6-R2\#1, 1945'36"S, 39 31'05”W, $92 \mathrm{~m}$ ), 2

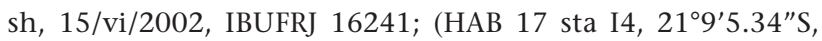
$\left.40^{\circ} 16^{\prime} 12.9^{\prime \prime} \mathrm{W}, 103 \mathrm{~m}\right), 1 \mathrm{sh}, 21 / \mathrm{vii} / 2009$, MNRJ 18406; (HAB 17 sta I2, $\left.21^{\circ} 22^{\prime} 54.3^{\prime \prime} \mathrm{S}, 40^{\circ} 19^{\prime} 50.6^{\prime \prime} \mathrm{W}, 53 \mathrm{~m}\right), 1 \mathrm{sh}, 21 / \mathrm{vii} / 2009$, MNRJ 18407; (HAB 13 sta I2, 2122'54.6”S, 40¹9'48.5”W, 52 m), 2 sh, 05/iii/2009, MNRJ 16239; (HAB 13 sta I4, 2122'55.2"S, $\left.40^{\circ} 15^{\prime} 31.5^{\prime \prime} \mathrm{W}, 103 \mathrm{~m}\right), 1 \mathrm{sh}, 06 / \mathrm{iii} / 2009$, MNRJ 16235; (HAB 13 sta H4, $\left.21^{\circ} 42^{\prime} 49.3^{\prime \prime} \mathrm{S}, 40^{\circ} 10^{\prime} 21.4^{\prime \prime} \mathrm{W}, 98 \mathrm{~m}\right), 10 \mathrm{sh}, 09 / \mathrm{iii} /$ 2009, MNRJ 16240; (HAB 13 sta H3, 21 ${ }^{\circ} 43^{\prime} 5.94^{\prime \prime} \mathrm{S}, 40^{\circ} 11^{\prime}$ 36.9”W, 73 m), 2 sh, 09/iii/2009, MNRJ 16228; (HAB 16 sta H3, $\left.21^{\circ} 43^{\prime} 6.41^{\prime \prime} \mathrm{S}, 40^{\circ} 11^{\prime} 37.0^{\prime \prime} \mathrm{W}, 71 \mathrm{~m}\right), 2 \mathrm{sh}, 07 / \mathrm{vii} / 2009$, MNRJ

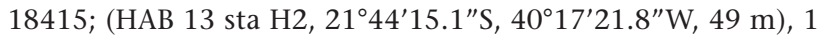
sh, 09/iii/2009, MNRJ16231. Rio de Janeiro: (HAB 16 sta G4, $\left.22^{\circ} 3^{\prime} 34.3^{\prime \prime} \mathrm{S}, 40^{\circ} 7^{\prime} 5.53^{\prime \prime} \mathrm{W}, 89 \mathrm{~m}\right), 2 \mathrm{sh}, 06 / \mathrm{vii} / 2009$, MNRJ

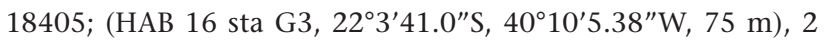
sh, 06/vii/2009, MNRJ 18399; (HAB 11 sta G3, 22³'41.2"S, $40^{\circ} 10^{\prime} 5.38^{\prime \prime} \mathrm{W}, 75 \mathrm{~m}$ ), 2 sh, 25/ii/2009, MNRJ 16234; (HAB 11 sta G4, 22 $\left.4^{\prime} 10.0^{\prime \prime} \mathrm{S}, 40^{\circ} 7^{\prime} 5.80^{\prime \prime} \mathrm{W}, 92 \mathrm{~m}\right), 4 \mathrm{sh}, 25 / \mathrm{ii} / 2009$, MNRJ

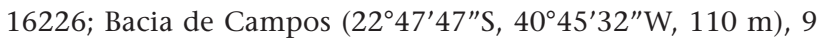
sh, 20-27/i/1998, AG leg., IBUFRJ 11793; (HAB 16 sta D5, $22^{\circ} 31^{\prime} 3.39^{\prime \prime}$, $\left.40^{\circ} 31^{\prime} 38.2^{\prime \prime} \mathrm{W}, 138 \mathrm{~m}\right), 1 \mathrm{sh}, 03 / \mathrm{vii} / 2009$, MNRJ 18370; (22 42'38.6"S, 4041'12.6”'W, $111 \mathrm{~m}), 1 \mathrm{sh}, \mathrm{iii} / 2007$,

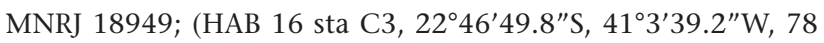
m), 1 sh, 02/vii/2009, MNRJ 18428; Bacia de Campos (2248'01"S, 4045'58"W, $110 \mathrm{~m}), 1 \mathrm{sh}$, iv/1998, AG leg., IBUFRJ

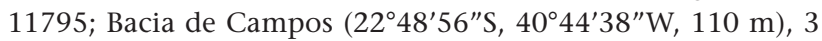
sh, iv/1998, AG leg., IBUFRJ 11794; (HAB 11 sta C4, $\left.22^{\circ} 51^{\prime} 57.5^{\prime \prime} \mathrm{S}, 40^{\circ} 57^{\prime} 35.1^{\prime \prime} \mathrm{W}, 92 \mathrm{~m}\right), 4 \mathrm{sh}, 22 / \mathrm{ii} / 2009$, MNRJ 16233; (HAB 16 sta C4, 22 51'57.5"S, 4057'34.8”'W, 90 m), 7 sh, 03/vii/2009, MNRJ 18377; (HAB 11 sta C5, 2257'23.9"S, $\left.40^{\circ} 50^{\prime} 36.4^{\prime \prime} \mathrm{W}, 142 \mathrm{~m}\right), 3 \mathrm{sh}, 21 / \mathrm{ii} / 2009$, MNRJ 16229; (230. $04^{\prime} \mathrm{S}$, $\left.40^{\circ} 59^{\prime} \mathrm{W}, 100 \mathrm{~m}\right), 13 \mathrm{sh}, 17 / \mathrm{xii} / 2004, \mathrm{MORG} 51297$; $\left(23^{\circ} 04^{\prime}\right.$ $\left.14.3^{\prime \prime} \mathrm{S}, 40^{\circ} 59^{\prime} 30.7^{\prime \prime} \mathrm{W}\right), 3 \mathrm{sh}, \mathrm{MNRJ} 15287$; (230.' $14.3^{\prime \prime} \mathrm{S}$, $\left.40^{\circ} 59^{\prime} 30.7^{\prime \prime} \mathrm{W}, 100 \mathrm{~m}\right), 2 \mathrm{sh}, 22 / \mathrm{iii} / 2005$ to $01 / \mathrm{iv} / 2005$, MNRJ
18951; (2304'14.3"S, 4059'30.7”W), 18 sh, 17/xii/2004, MNRJ

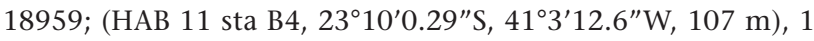
sh, 21/ii/2009, MNRJ 16238; (HAB 16 sta B4, 2310'0.72"S, $\left.41^{\circ} 3^{\prime} 12.5^{\prime \prime} \mathrm{W}, 107 \mathrm{~m}\right), 3 \mathrm{sh}, 02 / \mathrm{vii} / 2009$, MNRJ 18371; (HAB 11 sta B5, $\left.23^{\circ} 11^{\prime} 25.8^{\prime \prime} \mathrm{S}, 41^{\circ} 0^{\prime} 54.0^{\prime \prime} \mathrm{W}, 150 \mathrm{~m}\right), 13 \mathrm{sh}, 21 / \mathrm{ii} / 2009$, MNRJ 16237; (HAB 16 sta B5, 2312'4.20”'S, 4059'41.8”W, 141 $\mathrm{m}), 11 \mathrm{sh}, 02 / \mathrm{vii} / 2009$, MNRJ 18425; (HAB 11 sta A5, $\left.23^{\circ} 36^{\prime} 10.3^{\prime \prime} \mathrm{S}, 41^{\circ} 21^{\prime} 36.1^{\prime \prime} \mathrm{W}, 142 \mathrm{~m}\right), 1$ sh, 01/iii/2009, MNRJ 16172; Bacia de Campos, 1 sh, MORG 40794; Bacia de Campos, 1 sh, 2003, MORG 47453; Bacia de Campos, 1 sh, 2003, MORG 48095; Bacia de Campos, 1 sh, 2003, MORG 48104; Bacia de Campos, 1 sh, 2003, MORG 48533.

Geographic distribution. Bermuda (Аввотt 1974, Jensen \& Pearce 2009), USA: Florida (CAmp et al. 1998, Lee 2009), Louisiana (Rosenberg 2009), Texas (Tunnell Jr et al. 2010); Gulf of Mexico (Аввотt 1974), Bahamas (Redfern 2001), Cuba (Rolán \& Fernández-Garcés 1992), Jamaica (type locality), Costa Rica, Panama, Colombia (Rosenberg 2009), Aruba, Bonaire and Curaçao (ABC Islands) (Jong \& Coomans 1988); Brazil: Pará, Abrolhos Archipelago, Bahia to Rio de Janeiro (this study).

Remarks. Metaxia rugulosa (Figs 12-19) and M. excelsa (Figs 1-6) are similar in the shell shape and the sculpture pattern of the teleoconch. The main differences consist of the protoconch shape, which is slenderer in M. excelsa (Figs 2 and 4) and wider in M. rugulosa (Figs 13 and 15-18), and the number of whorls of the protoconch ( 4.5 in M. excelsa, 2.75 in M. rugulosa). In addition, the teleoconch of $M$. rugulosa is less shouldered (Fig. 12), with smaller nodules, and has a more nodulose subsutural cord (Fig. 19). Metaxia rugulosa exhibits variation in shell color, from white to brown. In contrast to the observations of Rolán \& Fernández-Garcés $(1992,2008)$, who described only white shells, and LEe (2009), who obtained a majority of white shells and a minority of homogeneously brown ones, the shells from Brazil are brown in most cases, with a few white shells. Rolán \& REDFERN (1996) provided a detailed study of the protoconch variation in M. rugulosa. Metaxia propinqua Rolán \& FernándezGarcés, 2008 is a very similar species, with minor differences in the protoconch sculpture, i.e., the presence of axial riblets only above the first spiral thread of the second whorl of the protoconch of $M$. propinqua, whereas the axial riblets of $M$. rugulosa run from the entire second whorl of the protoconch. However, this difference appears to be included in the variation described by RoLÁn \& REDFERn (1996) for the protoconch of $M$. rugulosa. Some of the shells from Brazil show axial riblets only above the upper spiral thread of the second whorl of the protoconch (Fig. 13), but these shells are herein considered as included in the variation of M. rugulosa. Another very similar species is Metaxia carinapex Linden, 1998, which is restricted to localities around the Cape Verde Archipelago. The teleoconch of $M$. carinapex is very similar to M. rugulosa, and its protoconch morphology seems to be included on the variation of $M$. rugulosa. A possible synonymy and consequent Atlantic distribution demands further study. Shells of $M$. 


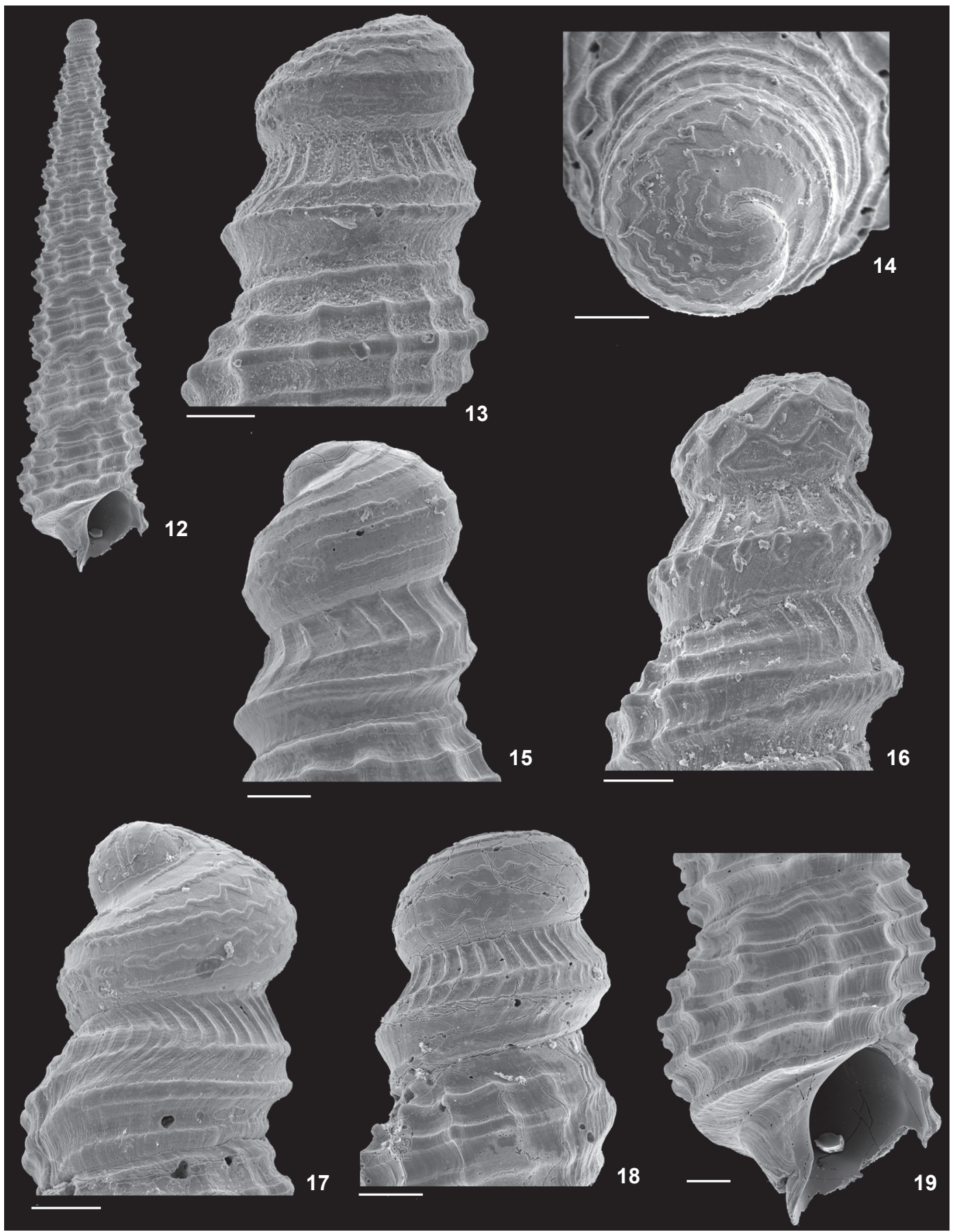

Figures 12-19. Metaxia rugulosa: (12) whole shell, length: $3.90 \mathrm{~mm}$; (13-18) protoconch; (19) last whorl. (12,18-19) MNRJ 18377, (13) IBUFRJ 18949, (14) MNRJ 18462, (15) MNRJ 16237, (16) IBUFRJ 18946, (17) MNRJ 18407. Scale bars: 13-18=10 $\mu \mathrm{m}, 19=200 \mu \mathrm{m}$.

taeniolata without a protoconch may be similar to white shells of $M$. rugulosa that also lack a protoconch, but $M$. taeniolata has well pronounced nodules on the intersections of the spi- rals with the axial lines. In addition, $M$. rugulosa never develops a light brown spot in the inter-nodular spaces of the second spiral row. 


\section{Metaxia prompta Rolán \& Fernández-Garcés, 2008}

Figs 20-24

Metaxia sp. 1: Leal (1991: 125, pl. 17, figs G-H).

Metaxia exilis: Absalão et al. (2006: 238, in part) non C.B. Adams, 1850.

Metaxia prompta: Rolán \& Fernández-Garcés (2008: 86, figs 2 D-J).

Type material: Holotype and two paratypes: FLMNH 359136 (not examined).

Type locality: Bermuda, Hamilton Parish, Shelly Bay.

Characterization. Shell elongated, slender and conical, reaching $5.7 \mathrm{~mm}$ in length and $1.1 \mathrm{~mm}$ in width. Protoconch narrow, with truncated apex, three whorls, outline slightly angled; first whorl with tapered apex, sculptured by strong, short pustules of irregular shape and size; remaining whorls with numerous axial ribs discontinuous at middle of the whorl, with summits partially covering the suture. Teleoconch with up to nine whorls and weakly developed shoulder; 21 axial ribs on fourth whorl, crossed by four spiral cords, the subsutural one being less prominent; a very small cord appears just above the shallow suture; axial sculpture very weak, sometimes disappearing even in the first whorls, and there are very small nodules or only slight elevations on the intersections with the spiral cords; smooth subperipheral cord on last whorl, base short and concave; aperture almost round, with an open siphonal canal; outer lip thin; columellar lip sinusoidal. Shell entirely white, sometimes golden-white.

Material examined. BRAzIL, Bahia: (REVIZEE sta C5-13R, $\left.16^{\circ} 47^{\prime} 08^{\prime \prime} \mathrm{S}, 38^{\circ} 41^{\prime} 08^{\prime \prime} \mathrm{W}, 50 \mathrm{~m}\right), 1$ sh, 30/vi/2001, IBUFRJ 13538. Espírito Santo: (REVIZEE sta C5-24R, $20.347^{\circ} \mathrm{S}, 36.642^{\circ} \mathrm{W}, 55 \mathrm{~m}$ ), 1 sh, 13/vii/2001, IBUFRJ 13573; (REVIZEE sta C5-23R, $20^{\circ} 29^{\prime} 03^{\prime \prime}$ S, 36 $\left.06^{\circ} 42^{\prime \prime} \mathrm{W}, 50-60 \mathrm{~m}\right), 15 \mathrm{sh}, 12 / \mathrm{vii} / 2001$, IBUFRJ

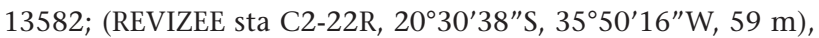
$1 \mathrm{sh}, 08 / \mathrm{xi} / 1997$, IBUFRJ 18948; (REVIZEE sta C5-21R, $\left.20^{\circ} 42.47^{\prime} \mathrm{S}, 35^{\circ} 27.41^{\prime} \mathrm{W}, 50-60 \mathrm{~m}\right), 1$ sh, 12/vii/2001, IBUFRJ 13601; (REVIZEE sta C5-21R, 20² $42.47^{\prime} \mathrm{S}, 35^{\circ} 27.41^{\prime} \mathrm{W}, 50-60 \mathrm{~m}$ ), 2 sh, 12/vii/2001, MNRJ 12732; Vitória-Trindade Chain: Jaseur Seamount (MD55 sta DC35, 20 $42^{\prime} \mathrm{S}, 35^{\circ} 22^{\prime} \mathrm{W}, 82-105 \mathrm{~m}$ ), 1 sh, 16/v/1987, MNRJ 25037; Columbia Seamount (MD55 sta DC47, 2042'S, 32¹3'W, 94-105 m), 1 sh, 19/v/1987, MNHN; Dogaressa Seamount (MD55 sta DC43, 20 $0^{\circ} 51^{\prime} \mathrm{S}, 33^{\circ} 45^{\prime} \mathrm{W}, 63$ m), 17/v/1987, 1 sh, MNHN; (MD55, Enseada dos Portugueses, Ilha de Trindade, 10-12 m), $1 \mathrm{sh}, \mathrm{MNHN}$.

Geographic distribution. Bermuda (type locality); Brazil: Bahia, Espírito Santo and Vitória-Trindade Chain (this study).

Remarks. Rolán \& REDFERN (1996) considered that Metaxia sp. 1, recorded by LeAL (1991) from southeast Brazil, actually referred to M. rugulosa. Examination of the shell illustrated by Leal (1991), as well as shells from other localities of southeast Brazil, furnished sufficient evidences to determine that material as $M$. prompta. The main difference between $M$. rugulosa (Figs 12-19) and $M$. prompta is in the protoconch, since $M$. prompta has a narrower protoconch, with a unique distribution of axial ribs (Figs 21 and 23). The weaker axial sculpture and the less shouldered shell of M. prompta (Fig. 20) are other important aspects to distinguish the two species.

\section{Metaxia gongyloskymnus sp. nov.}

Figs 25-31

Type material: holotype MORG 51299. Paratypes (one shell in each lot): IBUFRJ 18873 off Piúma, Espírito Santo state, 1993; MNRJ 30293; MORG 48456; MORG 48568; MORG 48642 type locality.

Type locality: Bacia de Campos, off Rio de Janeiro state, southeast Brazil (22 $\left.43^{\circ} \mathrm{S}, 40^{\circ} 40^{\prime} \mathrm{W}, 120 \mathrm{~m}\right)$.

Diagnosis. Protoconch globular and broad with slightly sinusoidal axial ribs continuous between adjacent whorls, and a single spiral cord; adapical region on second and third protoconch whorls with several microscopic spiral threads.

Description. Shell elongated, conical, reaching $4.1 \mathrm{~mm}$ in length, $1.1 \mathrm{~mm}$ in width. Protoconch globular and broad, with almost three whorls of convex to somewhat angled outline; first whorl with very thin, somewhat zigzag spiral threads; remaining whorls with 19 to 22 slightly sinusoidal axial ribs, almost continuous between adjacent whorls, and one spiral cord above suture, more evident at third whorl, with distance between spiral cord and suture around 1/3 of total height of whorl; several microscopic spiral threads on adapical region of second and third whorls. Teleoconch with up to six whorls of convex outline; axial sculpture formed by 16 to 18 weak ribs on third whorl, almost disappearing on last whorls; spiral sculpture formed by four cords, the adapical one less prominent, forming small nodules or only slight elevations on the intersections with the axial ribs; one additional small cord just above the impressed suture; smooth subperipheral cord; base short and concave; aperture almost round; open siphonal canal; outer lip thin; columellar lip sinusoidal. Shell white.

Etymology. gongylos, Gr. = round, spherical; skymnos, Gr. = young animal. This species is named after its globular protoconch (larval shell).

Geographic distribution. Southeast of Brazil: off Espírito Santo and Rio de Janeiro coasts.

Remarks. Metaxia gongyloskymnus (Figs 25-31) is unique among the species studied herein by having microscopic spiral threads on the protoconch (Fig. 30), between the adapical suture and the spiral cord. Metaxia gongyloskymnus has some variation in the protoconch, such as the number of axial ribs and the strength and position of the spiral cord. The holotype and most of paratypes have a larger number of axial ribs and a less marked spiral cord (Fig. 26), almost absent on the third whorl, whereas others have a well marked spiral cord (Fig. 28), forming a more angled outline of protoconch whorls. The most similar western Atlantic species to M. gongyloskymnus is Metaxia propria Rolán and Fernández-Garcés, 2008, from Florida, especially by the sharing of the continuous axial ribs on the whorls of the protoconch 


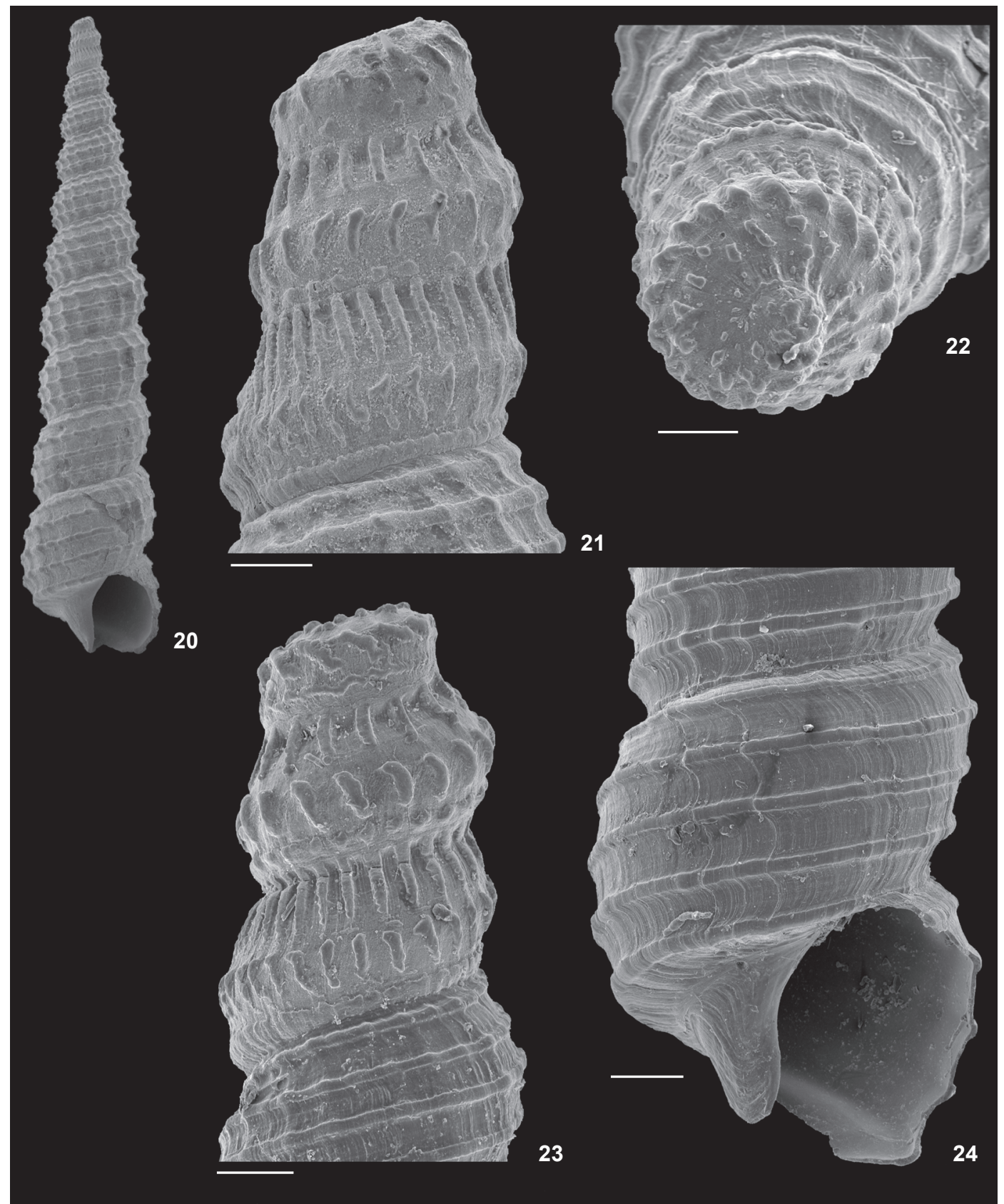

Figures 20-24. Metaxia prompta: (20) whole shell, length: $5.73 \mathrm{~mm}$; (21-23) protoconch; (24) last whorl. (20-21) MNRJ 25037, (22-23) IBUFRJ 13582, (24) IBUFRJ 12732. Scale bars: 21-23 = $100 \mu \mathrm{m}, 24=200 \mu \mathrm{m}$.

and some features of the teleoconch. Metaxia gongyloskymnus has a larger number of axial ribs on the protoconch and teleoconch, in addition to the slightly globular outline of the protoconch. While M. propria has two well defined spiral cords on the protoconch, all shells of M. gongyloskymnus here described bear only a weak (sometimes almost absent) lower spiral cord.
Also, M. propria lacks microscopic spiral threads on the protoconch whorls. Another similar species to M. gongyloskymnus is Metaxia hapax Linden, 1998, restricted to the Cape Verde Archipelago (Linden, 1998; Rolán, 2005), with the same pattern of continuous axial ribs between the whorls of the protoconch. Metaxia hapax presents fewer axial ribs on protoconch than $M$. 


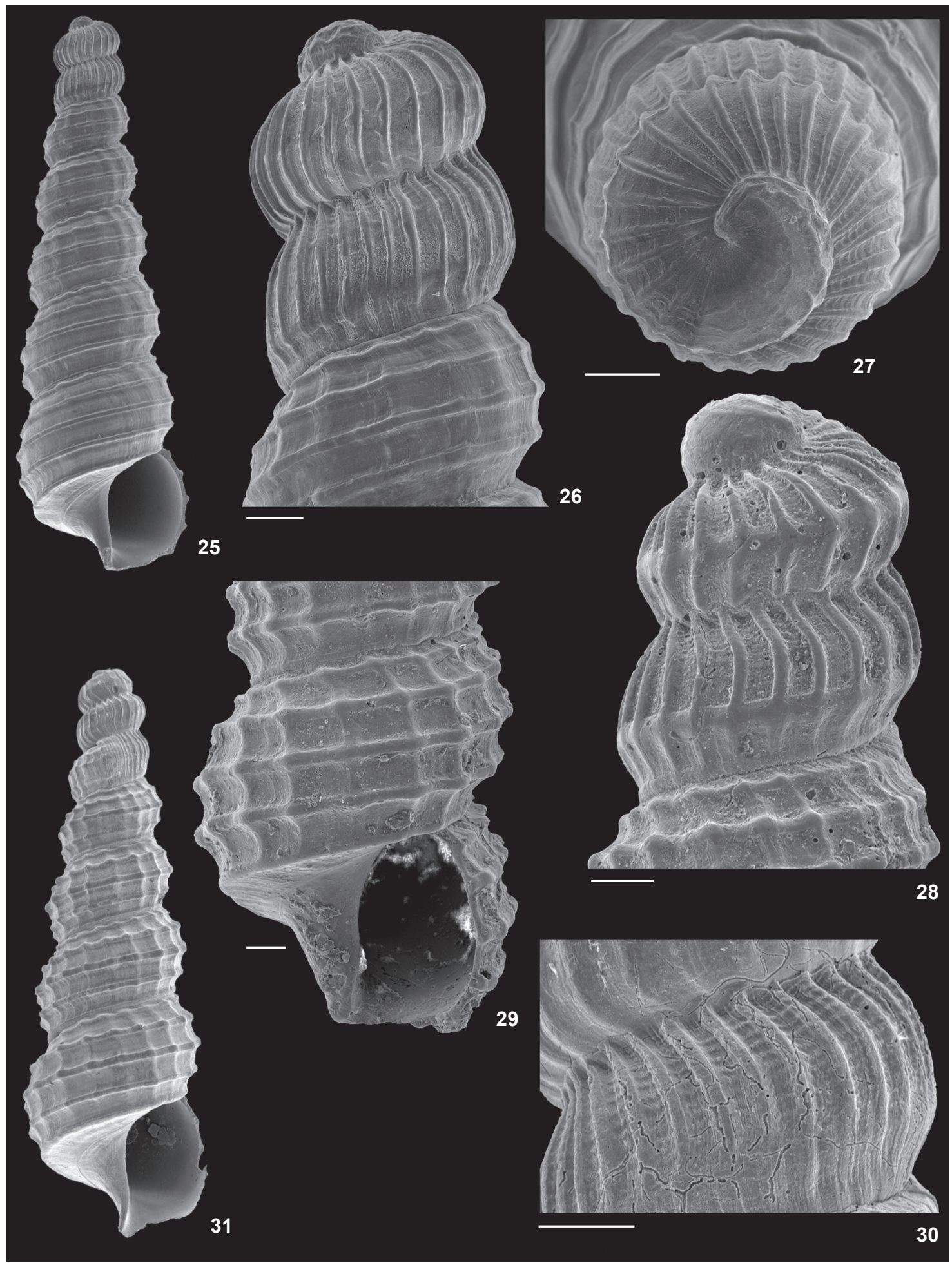

Figures 25-31. Metaxia gongyloskymnus sp. nov.: $(25,31)$ whole shells, respective lengths: 3.31, $3.55 \mathrm{~mm}$; (26-28) protoconch; (29) last whorl; (30) detail of the protoconch. (25-27) Holotype MORG 51299, (28-29) paratype IBUFRJ 18946, (30) paratype MORG 48456, (31) paratype MORG 48642. Scale bars: $26-30=100 \mu \mathrm{m}$. 
gongyloskymnus, and it lacks the spiral cord above suture and the microscopic spiral threads. Metaxia gongyloskymnus can be distinguished from M. rugulosa by its broader protoconch with a somewhat globular aspect and by the presence of continuous axial ribs along the entire length of the protoconch. Secondarily, the teleoconch of Metaxia gongyloskymnus has a weaker axial sculpture (Fig. 25). Metaxia gongyloskymnus shares with $M$. prompta the presence of weak nodules on the teleoconch, forming almost smooth spiral cords in some shells. However, axial ribs are visible in some shells (Figs 29 and 31). The aspects of the protoconch serve to separate them, including the broader shape and the typical distribution of the axial ribs in Metaxia gongyloskymnus (Figs 26 and 28).

\section{DISCUSSION}

Marshall (1977), while proposing Metaxiinae based on two species of Metaxia from the southwest Pacific, recognized two patterns of zigzag threads on the first whorl of the protoconch: numerous and closely spaced threads, almost in contact with each other, in Metaxia exaltata (Powell, 1930); or few and more widely spaced threads in Metaxia kermadecensis Marshall, 1977.

Among the species studied here, M. excelsa (Figs 2-4) and M. taeniolata (Figs 8 and 9) have a similar pattern to M. exaltata, while that of M. rugulosa (Figs 13-18) is similar to the pattern of Metaxia kermadecensis. Metaxia prompta (Figs 21-23), in contrast, has a distinct sculpture consisting of short pustules of irregular shape and size.

In Metaxia gongyloskymnus (Figs 26-28), the zigzag threads are most similar to the pattern of $M$. rugulosa, but they are less visible and restricted to the upper portion of the first whorl. The protoconch of M. gongyloskymnus is very similar to that of Metaxia maoria (Finlay, 1930), a species from New Zealand redescribed and illustrated by MarshaLl (1979), especially in the presence of continuous axial ribs between two adjacent whorls. However, the protoconch of $M$. maoria lacks a spiral cord, and the microscopic spiral lines are more numerous and distinct.

According to Rosenberg (2009) and Faber (2010), Metaxia is represented in the Western Atlantic by eleven species, all of them restricted to northern localities except for M. excelsa, the only species known from the southwestern Atlantic prior to this study.

The results obtained here show that other Metaxia species are widespread in the western Atlantic, as far south as around $21^{\circ} \mathrm{S}$. Metaxia rugulosa, M. taeniolata and M. excelsa have similar geographical distributions, from the southeast coast of the USA to the southeast coast of Brazil, with several records in the Caribbean region. Metaxia prompta, previously recorded only from its type locality (Bermuda), was found in Brazil, from off the Bahia to Rio de Janeiro coast, and it is also relatively widely distributed on the seamounts of the Vitória-Trindade Chain. Beside M. prompta, only M. excelsa occurs off the oceanic is- lands of Brazil, including the Vitória-Trindade Chain and the Fernando de Noronha Archipelago.

Metaxia gongyloskymnus is, up to now, known only from the Espírito Santo coast and the Campos Basin off the north coast of Rio de Janeiro.

\section{ACKNOWLEDGEMENTS}

We are grateful to Emilio Rolán, for providing bibliography and for comments on the taxonomy of Metaxia; to Paula Spotorno (MORG), Ricardo Absalão (IBUFRJ), Cláudia Rodrigues (UERJ), and Luiz Simone (MZUSP) for loan of material; José Henrique Leal (Sanibel Shell Museum), for sending the material of the MD55 expedition and for his criticism and suggestions on the manuscript; Amanda Veiga, for operating the SEM at the Departamento de Invertebrados (MNRJ); Janet Reid, for revising the English text; one anonimous referee for his criticism; Petrobras, for making the collection and study of material from the Habitats Project possible; CNPq/PIBIC/UFRJ for providing a grant of scientific initiation to $\mathrm{M}$. Fernandes.

\section{LITERATURE CITED}

Аввотт, R.T. 1974. American Seashells. New York, Van Nostrand Reinhold, 2nd ed., 663p.

Absalão, R.S.; C.H.S. Caetano \& R.R. Fortes. 2006. Filo Mollusca, p. 211-260. In: H.P. Lavrado \& B.L. Ignacio (Eds). Biodiversidade bentônica da região central da Zona Econômica Exclusiva Brasileira. Rio de Janeiro, Museu Nacional, Série Livros 18, 389p.

Adams, C.B. 1850. Descriptions of supposed new species of marine shells wich inhabit Jamaica. Contributions to Conchology 7: 109-123.

Appeltans, W.; P. Bouchet; G.A. Boxshall; K. Fauchald; D.P. Gordon; B.W. Hoeksema; G.C.B. Poore; R.W.M. van Soest; S. StÖHr; T.C. Walter \& M.J. Costello. 2011. World Register of Marine Species. Available online at: http://www.marinespecies.org [Acessed: 1.VIII.2011].

BoucheT, P. 1985. Les Triphoridae de Mediterranee et du proche Atlantique (Mollusca, Gastropoda). Lavori Società Italiana di Malacologia. 21: 5-58.

Camp, D.K.; W.G. Lyons \& T.H. Perkins. 1998. Checklist of Selected Shallow-Water Marine Invertebrates of Florida. St. Petersburg, Florida Marine Research Institute, Technical Report, 3, 238p.

Clench, W.J. \& R.D. Turner. 1950. The Western Atlantic Marine Mollusks Described by C.B. Adams. Occasional Papers on Mollusks 1 (15): 233-403.

Cossmann, 1906. Essais de paléoconchologie comparée, 7. Paris, The Author and Rudeval, 215p.

DALL, W.H. 1889. Reports on the results of dredging, under the supervision of Alexander Agassiz, in the Gulf of Mexico (187778) and in the Caribbean Sea (1879-80), by the U.S. Coast Survey steamer "Blake" Lieut.-Commander C.D. Sigsbee, 
U.S.N., and Commander J.R. Bartlett, U.S.N., commanding. XXIX. Report on the Mollusca. Part 2, Gastropoda and Scaphopoda. Bulletin of the Museum of Comparative Zoology 18: 492.

FABER, M.J. 2010. Marine gastropods from the ABC islands and other localities 35. A new species of Metaxia (Gastropoda: Triphoridae). Miscellanea Malacologica 4 (3): 30.

Faber, M.J. \& R.G. Moolenneer. 1991. Two new shallow water triphorids and a new name in Metaxia from Florida and the West Indies. Apex 6 (3-4): 81-85.

Fernandes, F. \& E. Rolán. 1994. Check-list of the amphiatlantic mollusca based on a revision of the literature. Reseñas Malacológicas 8: 3-36.

Gomes, R.G.; P.M.S. Costa; J.C. Monteiro; A.C.S. Collho \& N.C. SALGADO. 2006. Moluscos das Ilhas Oceânicas Brasileiras, p. 180-198. In: R.J.V. Alves \& J.W.A. CASTRO (Eds). Ilhas oceânicas brasileiras da pesquisa ao manejo. Brasília,Ministério do Meio Ambiente, 340p.

Jensen, R.H. \& T.A. Pearce. 2009. Marine Mollusks of Bermuda - Checklist and Bibliography. Delaware Museum of Natural History, $\mathrm{X}+473 \mathrm{p}$.

Jong, K.M. \& H.E. Coomans. 1988. Marine Gastropods from Curaçao, Aruba and Bonaire. Leiden, E.J. Brill, 261p.

LEAL, J.H. 1991. Marine Prosobranch Gastropods from Oceanic Islands off Brazil: Species Composition and Biogeography. Oegstgeest, Universal Book Services, $\mathrm{X}+418 \mathrm{p}$.

Lee, H.G. 2009. Marine Shells of Northeast Florida. Jacksonville, Shell Club, 204p.

Linden, J. VAn Der. 1998. The Metaxiinae dredged by the CANCAP expeditions, with the new species Metaxia carinapex and Metaxia hapax from the Cape Verde islands (Gastropoda, Heteropoda; Triphoridae). Basteria 61 (4-6): 115-122.

Marshall, B.A. 1977. The dextral triforid genus Metaxia (Mollusca: Gastropoda) in the south-west Pacific. New Zealand Journal of Zoology 4: 111-117.

Marshall, B.A. 1979. Additional dextral triphorids (Mollusca: Gastropoda) from New Zealand. New Zealand Journal of Zoology 6: 397-404.

Marshall, B.A. 1983. A revision of the recent Triphoridae of Southern Australia (Mollusca: Gastropoda). Records of the Australian Museum 2: 1-119.

Merlano, J.M.D. \& M.P. Hegedus. 1994. Moluscos del Caribe Colombiano. Santa fe de Bogota, Colciencias, Fundación Natura, Invemar, 291p.

Redfern, C. 2001. Bahamian Seashells - A Thousand Species from Abaco, Bahamas. Boca Raton, Bahamianseashells Inc., IX+261p.

Rios, E. 1970. Coastal Brazilian Seashells. Rio Grande, Museu Oceanográfico do Rio Grande, 255p.

Submitted: 19.VIII.2011; Accepted: 19.X.2011 Editorial responsibility: Marcos D.S. Tavares
Rios, E. 1975. Brazilian Marine Mollusks Iconography. Rio Grande, Museu Oceanográfico da FURG, 331p.

Rios, E. 1985. Seashells of Brazil. Rio Grande, Museu Oceanográfico da FURG, 328p.

Rios, E. 1994. Seashells of Brazil. Rio Grande, Museu Oceanográfico da FURG, $2^{\text {nd }}$ ed., 368 p.

Rios, E. 2009. Compendium of Brazilian Seashells. Rio Grande, Evangraf, VIII+668p.

Rolán, E. 2005.Malacological Fauna from the Cape Verde Archipelago. Hackenheim, ConchBooks, 455p.

Rolán, E. \& C. Redfern. 1996. Variabilidad de la protoconcha de Metaxia rugulosa (C.B. Adams, 1850) (Gastropoda; Triphoridae). Noticiario de la Sociedad Española de Malacologia 26: 2729.

Rolán, E. \& R. Fernández-Garcés. 1992. La Famiglia Triphoridae (Mollusca: Gastropoda) em la isla de Cuba 1: el género Metaxia Monterosato, 1884. Bollettino Malacologico 28 (512): $169-176$.

Rolán, E. \& R. Fernández-Garcés. 2007. Caribbean Triphoridae (Gastropoda: Triphoroidea): list and colour ilustrations. Neptunea 6 (3): 13-24.

Rolán, E. \& R. Fernández-Garcés. 2008. New data on the Caribbean Triphoridae (Caenogastropoda, Triphoroidea) with the description of 26 new species. Iberus 26 (1): 81-170.

RosenberG, G. 2009. Malacolog 4.1.1: A Database of Western Atlantic Marine Mollusca, version 4.1.1 Available online at: http://www.malacolog.org [Accessed: 16.VIII.2011].

Santos, F.N.; C.H.S. Caetano; R.S. Absalão \& T.S. de Paula. 2007. Mollusca de substrato não consolidado, p. 207-236. In: J.C. Creed; D.O. Pires \& M.A.O. Figueiredo (Eds). Biodiversidade Marinha da Baía da Ilha Grande. Brasília, Ministério do Meio Ambiente, 416p.

Tunnell Jr, J.W.; J. Andrews; N.C. Barrera \& F. Moretzsohn. 2010. Encyclopedia of Texas Seashells - Identification, Ecology, Distribution \& History. College station, Harte Research Institute for Gulf of Mexico Studies Series, XI+512p.

VerRIL, A.E. \& K.J. Bush. 1900. Additions to the marine Mollusca of the Bermudas. Transections of the Connecticut Academy of Arts and Sciences 10: 513-544.

VOKES, H.E. \& E.H. VOKES. 1983. Distribution of Shallow-Water Marine Mollusca, Yucatan Peninsula, Mexico. New Orleans, Mesoamerican Ecology Institute, Middle American Research Institute, VIII+183p.

WelLs, F.E. 1998. Superfamily Triphoroidea, p. 808-811. In: P.L. BeEsley,; G.J.B. Ross \& A. Wells (Eds). Mollusca: The Southern Synthesis. Fauna of Australia. Melbourne, CSIRO Publishing. Part B, vol. 5, VIII+565-1234p.

Wilson, B. 1993. Australian Marine Shells - Prosobranch Gastropods, part one. Kalaroo, Odyssey Publishing, 408p. 